\title{
Conditions for the Russian Federation Arctic zone innovative development
}

\author{
I $N$ Guzov $^{1, *}, N A$ Polyakov $^{1}, V O$ Titov $^{1}$, and $A E$ Vashchuk $^{1}$ \\ ${ }^{1}$ St. Petersburg State University, 7/9 Universitetskaya nab., St. Petersburg, 199034 Russia
}

\begin{abstract}
The article is devoted to the questions concerning the formation of conditions for the implementation of innovative potential of the Arctic Zone of the Russian Federation. A comprehensive solution to the problems of development of the Arctic should be associated with the creation of reference zones of advanced development in the Arctic regions, in which a number of tasks need to be performed. It is necessary to determine the markets of scientific and technical products and technologies as priorities for the development of the Arctic zone of the Russian Federation. It is necessary to develop innovative territorial clusters and to create favorable conditions for the development of innovative activities, both large companies and small businesses; to stimulate private investment in the economy of the Arctic regions; to create special economic zones in the Administrative centers of the regions.
\end{abstract}

\section{Introduction}

The study was carried out as part of a research project supported by St. Petersburg State University: "Urbanized Ecosystems of the Arctic Belt of the Russian Federation: Dynamics, Condition and Sustainable Development" (PURE Id: 11752931)

Land development of the RF Arctic Zone (AZRF) is nowadays a key element of the energy safety of Russia.

The AZRF territory includes the territories of municipalities and territorial regions of the RF: Murmansk Region, Nenets Autonomous District, the Chukotka Autonomous District, Yamalo-Nenets Autonomous District, the Republic of Karelia, the Komi Republic, the Republic of Sakha (Yakutia), Krasnoyarsk Region and Arkhangelsk Region.

The revised version of Governmental programme of AZRF socio-economical development extends the period of its implementation up to 2025 , definitizes the stages and sets priorities in the form of separate Subprogrammes (including Federal Special Purpose Programmes), such as "Organization of pivot zones of development and insuring their operation, creation conditions for speed up socio-economical development of the RF Arctic zone", "The development of the Northern Sea Route and supporting shipping traffic in the Arctic zone"; "Manufacturing equipment and creation of technologies of oil-and-gas and industrial mechanic engineering required for reclamation of the RF Arctic zone mineral resources". [1].

\section{Methods}

The federally allocated budget for the implementation of plans of socio-economical development until 2025 amounts to more than $190 \mathrm{bn}$. roubles, Figure 1.

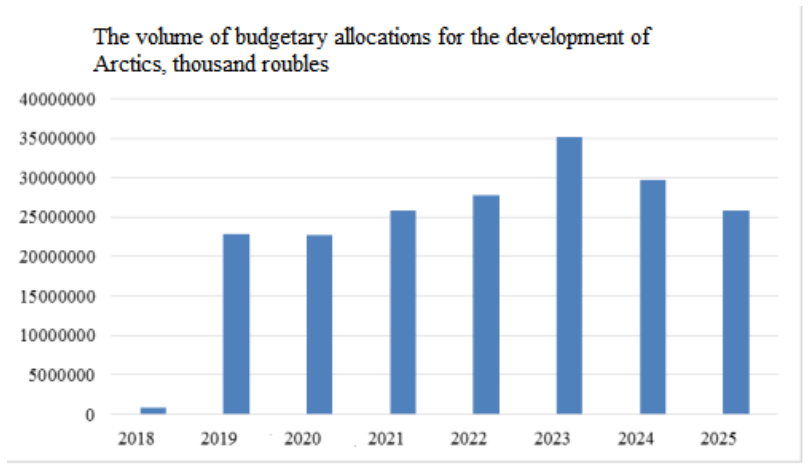

Fig. 1. State funding for the socio-economic development of the Arctic.

According to the results of statistical observation in the AZRF business activity of enterprises and industrial production turnover are growing (Table 1), in 2018 the volume of cargo carriage on the Northern Sea Route grew up to 19,7 mntpa which is an unprecedented value throughout the history of development of the Arctic region.

The priorities of development of the Arctic region are set forth in the Governmental programme and the Strategy for AZRF development. They include commercial development of Arctic shelf; scientific and technological advancement for the aims of efficient use of natural resources; construction of transport

\footnotetext{
* Corresponding author: npregion@mail.ru
} 
Table 1. Turnover of organizations, thousand rubles.

\begin{tabular}{|l|c|c|c|}
\hline & $\mathbf{2 0 1 6}$ & $\mathbf{2 0 1 7}$ & $\mathbf{2 0 1 8}$ \\
\hline Arctic zone of the Russian Federation & 4764495054 & 5570764783 & 6919015253 \\
\hline For reference: the Russian Federation & 112002268928 & 122213694495 & 144029840496 \\
\hline
\end{tabular}

infrastructure; national security and environment preservation. All the abovementioned figures and facts show that the development of the RF Arctic zone in the recent years turned into one of the most crucial tasks of Russian economics.

The Arctic region is a field of increased focus of Arctic nations. Thus, following the Ottawa declaration, the Arctic Council includes such countries as Canada, the Kingdom of Denmark, Finland, Iceland, Norway, the Russian Federation, Sweden and the United States of America. Within the frames of the Council activity the major tasks of intergovernmental coordination center around environment protection and improvement of living environment of the Arctic communities. Nevertheless, economical, commercial and security issues are the key directions for the certain states.

International companies pay a great attention to the development of the Northern Sea Route and the raw materials and resource base of the Russian Arctic, despite serious limitations on the use of technologies in energy sector of Russia set by the Western partners. Such companies as Total, CNPC, CNOOC, Saudi Aramco, Saibu Gas Co. take part in the new projects of the Arctic fuel and energy complex.

\section{Results}

AZRF development is tightly related to the application of innovative technologies, which is especially relevant in the setting of the recent sanctions pressure on Russia. The innovation-based development of regions is the key factor for the competitive ability of the territory. The regions of AZRF should think over the possibilities of their innovative capacity realization.

In the Government of the RF innovation-based development of the territory is considered to be related to the creation of pivot points, so-called points of economic growth within Arctic regions; construction of the Northern Sea Route infrastructure; reclamation of continental shelf by applying advanced technologies and cutting-edge equipment. The plans of Arctic regions are first of all connected with the resolution of social security problems, implementation of engineering and transport infrastructure projects. Though, in the authors' point of view, the complex solution to the problems of Arctic development should be associated with the creation of priority development pivot zones in these districts; the implementability of innovative capacity of the territory should be the most crucial issue in such zones.[2-11] In order to perform this task, it is necessary to fulfil a set of conditions.

The development of sci-tech and technologies markets as priority markets of the RF regions
In order to promote competitions in the RF regions, the Government along with the socially important markets suggested a mechanism of creation priority markets. The standard of competition promotion defines priority markets as non-resource markets having high export and import substitution capacity within the frames of production and innovation clusters located on the Russian territory. Sci-tech market and market of advanced technologies needed for AZRF development could become such markets. Of course, it is important to take into account the specifics of Northern territories and the topical regional issues when creating such markets. [12-15].

Development of innovative-territory clusters.

The creation of innovative clusters suggests activation of science-based and high-tech business along the priority directions of the Russian Arctic development [16]. The long-term socio-economical development roadmap of the Russian Federation for the period up to 2020 lays basis for cluster development; the transition to innovative type of economical development of Russia is defined there as "transition to a new model of spatial development of Russian economy, including the creation of new socio-economical development centers based upon the growth of energy and transport infrastructure and creation of chain of territorial-production clusters realizing competitive capacity of the territories". Clusters give an opportunity to build a system of spreading new knowledge, contribute to efficient cooperation of economic entities; set new directions in business, including science-based and high-tech ones; accelerate innovation processes which is a great competitive advantage of the region.[16-18]. Taking into account the defined priorities of AZRF socio-economical development, the focus is put upon clusters of the following enterprises: information and communication technology, radionics and instrument-making, oil and gas processing, geological exploration, industrial mechanic engineering, mining industry, iron and steel industry, shipbuilding, nuclear and radiation technology, environment preservation. Environment safety in the development of new territory as well as Arctic shelf, socalled cleantech is one of the most promising directions of cluster development [2].

Innovative policy of the regions: supportive measures for innovative ventures; creation ecosystem of innovative activity

The build-up of Arctic regions clusters should be related to the science-based business in which key role should be played by small innovative enterprises. It is essential to view the mechanism supporting development of small innovative business from the point of competition promotion within the territory of the RF Arctic zone. 
All over the world, growth prospects of this direction are determined with activation of small innovative business, including University enterprises; increased interest of the society to the sphere of ecology, governmental support or R\&D sphere enterprises, fashionable trend for cleantech. In our opinion, one of the promising directions of the RF Arctic regions innovative development is creation of favourable conditions for the enterprises implementing ecological innovations within AZRF.

Innovative development of the territory largely depends on understanding the need for construction a competitive business in the region by the local legislative and executive power. Innovative policy is set forth in the Programme of socio-economical development and separate legislative acts in the sphere of innovations.

The authors suggest that the crucial issue of the regional innovative ecosystem should be infrastructural objects orientation towards supporting business related to the Russian Arctic development.

Creation of special technology development economic areas in the regional capitals of Arctic regions

Activation of innovative business is also possible within the frames of creation special technology development areas (STDA) on the areas surrounding ASRF. Russian experience of creating such structures is more than 10 years. The idea of creation special economic zones was aimed to stimulate the activity of economic entities along the priority directions of economic growth: industrial production, innovative technologies, port facilities and tourism. Though, this status is a feature of economically advanced regions and judging by the innovative growth, the regions with this status are the leaders among federal subjects. This first of all, occurs due to the regionally presented criteria: stable economy and an experience of participation in large investment projects.

There are different options of locating STDA in AZRF but from the viewpoint of the best possible location and saving money on infrastructural facilities, it is sensible to organize them in the region capitals of the RF subjects.

Interaction of the key players of AZRF with scientific centers and higher education institutions with the purpose of preparing skilled staff and holding cooperative research and development activity

The growth prospects of resource-extracting companies which are the key participants of Arctic development, such as PJSC Gazprom, PJSC NK Rosneft , PJSC Lukoil are related to plans of innovative activity of these companies. Among the major documents regulating innovative business processes there are the Programme for innovation growth of PJSC Gazprom for up to 2025, the Programme for innovation growth of OJSC NK Rosneft for 2016-2020 with the prospects for up to 2030; the Programme of strategic development of LUKOIL group for 2012-2021. Higher education institutions and the leading scientific centers ensure influx of new technologies to these companies. Thus, PJSC NK Rosneft has planned to create R\&D facilities and innovations centers at higher education institutions in the form of organizing joint research programmes. Is is planned to outsource $R \& D$ for the needs of business to the Universities, scientific organizations and R\&D enterprises. The company has worked out a roadmap on staff recruiting and training which includes participation in the principal educational programs in cooperation with 34 partner higher education institutions.

Increasing influence of governmental Institutes for development

Governmental Institutes for development are aimed to accelerate the processes of the Russian Federation economy modernization. Business is stimulated to develop technologies in AZRF [21-23] thanks to the orientation of such institutes to the support of innovations and R\&D financing. Their task is also focused on implementation of projects which despite being low efficient are still a priority for the economy of the country. These are large-scale projects of exploitations, development of the Northern Sea Route as well as national security. The major Institutes for development include:

- Skolkovo Innovation center;

- JSC RUSNANO;

- JSC RVK;

- ST Rostec;

- Russian Foundation for Fundamental Research;

- Innovation Promotion Fund;

- Industrial Development Fund.

Stimulation of inflow of private investments into the regional economy.

The inflow of investments makes it possible to implement new technologies in Arctic development. A remarkable example is a project of construction LNGfacility in Sabetta (YNAO) with the capacity 16,5 mntpa. The estimated project cost is 27 billion USD. The engineering and manufacturing complex is located on the resource bas of South Tambeyskoe field. The project operator is a joint company JSC Yamal-SPG. Among the stakeholders there are JSC NOVATECH (50,1\%), TOTAL group of companies $(20 \%)$, Chinese Oil and Gas Corporation (20\%), Silk Road Fund (9,9\%). Gas will be supplied to the European and AP region markets. The project is unique because it resolves a number of complicated problems: construction of port and infrastructure in severe climatic conditions [24]; new solutions are used in shipbuilding to service the facility, in particular, new tankers which transport gas without icebreaker support and there is also the facility itself which has three processing lines of gas liquefaction.

\section{Conclusion}

Following the results of the study, it is necessary to draw major conclusions:

1. The overall development of AZRF should be directly related to realization of innovative potential of the territory.

2. It is necessary to create priority markets for the Arctic regions, primarily from the perspective of AZRF development. 
3. The development of enterprises and organizations clusters of the same sci-tech chain in Arctic is a priority direction of socio-economical AZRF growth.

4. Creating conditions for the elaboration of home-grown technologies in the sphere of natural environment protection or so-called cleantech is one of the most promising directions of cluster development. The construction of clusters should be connected with science-based business with the key role assigned to the small innovative enterprises.

5. An important task of regional innovation policy is the regional ecosystem of innovations with orientation of infrastructure facilities to support business dealing with the Russian Arctic development.

6. There are options of locating STDA in the capitals of AZRF regions within the frames of the effective legislation.

7. The implementation of innovative development programmes of resource-extracting companies in cooperation with Universities and scientific centers determines the competitive advantage of business, involves the scientific, educational and innovative potential of higher education institutions.

8. The role of governmental Institutes for development is crucial for the innovative development of the territory. Moreover, their activity is focused on implementation of the priority projects of exploitations, the Northern Sea Route development and national security. [27].

\section{References}

[1] A.M. Konovalov, Arctic:national interests in the context of globalization, Digest-finance, 1, 205, 32-40 (2012).

[2] N.A. Polyakov, V.V. Chipizubov, Innovative ecology efficient technologies of small business in development, Arctic zone of the Russian Federation, Innovations, 10, 228, 61-68 (2017).

[3] M.V. Sutugina, E.E. Sklyarova, Innovative potential of Russian regions as a factor of economic growth, Scientific and methodical online magazine Concept, 12, 66-71 (2016) [Electronic resource]. Available at: http://ekoncept.ru/2016/46214.htm.

[4] N.A. Polyakov, Specific features of infrastructure of innovations development in the Russian Federation, Bulletin of Saint-Petersburg State University, Economics, 1, 38-46 (2011).

[5] A-S. Crepin, M. Karcher, J-C. Gascard, Arctic Climate Change Economy and Society: Integrated perspectives Ambio, 46, 3, 341-354 (2017). DOI: 10.1007/s13280-017-0953-3.

[6] P. Hemmersam, Arctic architectures, Polar Record, 52, 4, 412-422 (2016). DOI: 10.1017/S003224741500100X.

[7] W. Greaves, Securing sustainability: the case for critical environmental security in the Arctic, Polar Record, 52, 6, 660-671 (2016). DOI: $10.1017 / \mathrm{S} 0032247416000218$.

[8] A.A. Popov, A.N. Myreev, V.V. Sergeeva, The model of priority economic and social sphere development of the districts (uluses) of the Thule and the Arctic zone, The problems of modern economics, 1, 53, 238241 (2015).

[9] V.N. Lazhentsev, Socio-economic space and territorial development of the North and Arctic of Russia, Economy of the region, 14, 2, 353-365 (2018).

[10] V.S. Selin, E.P. Bashmakova, Priorities of the modern governmental strategies for Arctic regions development, Region, Economic and sociology, 1, 3-2 (2013).

[11] V.N. Leksin, B.N. Porfiriev, Socio-eocnomic priorities of sustainable development of the Arctic macroregion of Russia, Economy of the region, 13, 4, 985-1004 (2017).

[12] L.D. Hinzman, C.J. Deal, A.D. McGuire, S.H. Mernild, I.V. Polyakov, J.E. Walsh, Trajectory of the Arctic as an integrated system, Ecological Applications, 23, 8, 1837-1868 (2013). DOI: 10.1890/11-1498.1.

[13] V.N. Leksin, B.N. Porfiriev, Governmental control of the Arctic zone of the Russian Federation development (Scientific adviser, Moscow, 194, 2016).

[14] M.V. Kurneva, Evaluation of efficiency of geological surveys performed according to the scheme of public-private partnership, The problems of modern economics, 1, 53, 260-262 (2015).

[15] N.V. Pakhomova, K.K. Rikhter, G.B. Malyshkov, Y.P. Bondarenko, Organizational and institutional conditions of demand generation, Bulletin of Saint-Petersburg State University, Economics, 2, 4-33 (2015).

[16] T.Y. Kovaleva, The algorithm of identification and evaluation clusters in the economy of the region, Bulletin of the Perm State University, Economic Series, 4, 30-39 (2011).

[17] V.N. Leksin, B.N. Porfiriev, Evaluation of the Effectiveness of Government Programs of Socioeconomic Development of Regions of Russia, Studies on Russian Economic Development, 4, 27, 418-428 (2016).

[18] K-J. Dodds, Anticipating the Arctic and the Arctic Council: pre-emption, precaution and preparedness, Polar Record, 49, 2, 412-422 (2013). DOI: $10.1017 /$ S0032247412000198.

[19] V.N. Borisov, O.V. Pochukaeva, Correlation of factors of the RF Arctic zone development, Problems of forecasting, 2, 59, 68 (2016).

[20] V.N. Leksin, B.N. Porfiriev, Mid-and long-term scientific and institutional potential of integral development of Arctic, Problems of forecasting, 6, 58-66 (2015).

[21] I.E. Frolov, Development of the Russian zone of Arctic: issues of recreating transport and military infrastructures, Problems of forecasting, 6, 67-74 (2015).

[22] Arctic: standardization as a tool of sustainable development, Standards and quality, 3, 969, 3033 . 
[23] D.C. Nord, The changing Arctic, Creating a Framework for Consensus Building and Governance within the Arctic Council, Palgrave Macmillan, New York, 186, 9-21 (2016). DOI: 10.1057/9781137501868.

[24] N.I. Komkov, V.S. Selin, V.A. Tsukerman, E.S. Goryachevskaya, Scenario forecast for the Northern Sea Route, Problems of forecasting, 2, 87-98 (2016). 